\title{
The Visual Memory of William Perkins and the End of Theological Dialogue
}

John G. Rechtien

\begin{abstract}
The article approaches Reformation theology over a route in the history of consciousness heretofore only partially explored - changing modes of conceptualizing and organizing thought as related to the use of print. The pivotal role of theological commonplaces in the transition of paradigms of thought from rhetorical to visually methodic is examined by analyzing their place in the Ramist structure of William Perkins' The Art of Prophecying.

The study undertakes to explicate Perkins' way of organızing and purveying knowledge for theological and homiletic purposes, with awareness of the fact that Perkins' program for homiletic actually serves as an indicator to us of what was going on to a greater or lesser degree throughout the intellectual world of the time. The way Puritan and Ramist sensibilities were fused in Perkins' book will be seen to llumınate how reasoning became patterned according to a paradigm of two visual memory systems, ultimately effecting the displacement of authority sources. The resulting visual paradigm of "plain style" excluded the possibility of theological dialogue.

The essay is divided into three parts. First, the visual structure of Puritan thought patterns is related to the cultural context. The affinity between Ramist logic and its dichotomous "method" on the one hand, and Puritanism on the other is explained. Various types of commonplaces are defined.

The second, and major, section outlines the visual structure of The Art of Prophecying. Perkins' organization combines the visual memory of texts with the mnemonic structure of Ramist method. References to commonplaces occur within each of the principal Ramist dichotomies which explicate "prophecying," that is, within the discussions of the "parts" of preaching and within the brief exposition of prayer. The book can be outlined in a Ramist chart. The book's contents recommend and apply commonplaces, even documenting directives for organizing and keeping a commonplace book.

The third section of the essay interprets the significance of Perkins' visual memory techniques. A chapter by Perkins about the role of memory in preaching takes up the Bruno-Dicson controversy about mnemonic technique at Cambridge in 1584 and outlines the second book of Ramus' Logic to displace traditional logic and rhetoric as well as Bruno's arcane visual technique. Perkıns' obsession with memory is seen as exemplifyıng a crucial moment in the gradual shift of the sensorium from oratorical thought patterns to a visually arranged cognitive process of private thinking.

The literary structures of sixteenth and seventeenth century Reformed and Catholic theologians testify to a reorganization of the sensorium which affected the way men thought as well as the way they theologized. With the rise of the visual rationalism of which Ramist method was an early symptom, logic swallowed up rhetoric and then became silent.
\end{abstract}

John G. Rechtien (S.T.L. Fribourg, Switzerland; Ph.D., St. Louis University) is assistant professor at St. Mary's University, San Antonio, Texas, where he teaches literature, linguistics, and theology. He has published articles in the English Journal, Marıanist Educator, Texas Studies in Literature and Language, Renaissance Quarterly, Sixteenth Century Journal, and Centerpoint. 